\title{
Extended grazing: A detailed analysis of Irish dairy farms
}

\author{
D. Läpple, ${ }^{\star 1}$ T. Hennessy, ${ }^{\star}$ and M. O’Donovan† \\ ${ }^{*}$ Agricultural Economics Department, Rural Economy and Development Programme, Teagasc, Athenry, Co. Galway, Ireland \\ †Animal and Grassland Research and Innovation Centre, Teagasc, Moorepark, Fermoy, Co. Cork, Ireland
}

\begin{abstract}
Profitability and factors affecting grazing season length were econometrically analyzed using a representative sample of Irish dairy farms. The objective of this study was to explore what potential exists on Irish dairy farms to extend the grazing season and to quantify the possible economic benefits that result from lengthening the grazing season. Regression results indicate that location factors affect the length of the grazing season, but even when physical factors are controlled, farmer characteristics, such as education, also affect the grazing season length. The results of a panel data analysis show that significant cost reductions can be achieved by extending the grazing season. Overall, the findings indicate that lengthening the grazing season offers a cost-saving alternative on many Irish dairy farms, which could contribute to strengthening the competitiveness of the Irish dairy sector.
\end{abstract}

Key words: grazing, dairy farm, milk production

\section{INTRODUCTION}

Producing milk from a low-cost grass-based system in a temperate climate is where Irish farmers can excel and gain advantage in the global food market. This low-cost grass-based system is regarded as the main competitive advantage of Irish dairy farming. Indeed, recent studies of the international competitiveness of dairy farming have identified Ireland as being one of Europe's leading low-cost milk producers (Thorne and Fingleton, 2006; Dillon et al., 2008). Nevertheless, to keep costs at a minimum, it is important that dairy farmers make as much use as possible of the large amount of grass that can be grown in Ireland (this analysis is conducted on dairy farms in the Republic of Ireland, hereafter referred to as Ireland).

Irish dairy farming is characterized by spring-calving, pasture-based systems, using grass as the main feed source for dairy cows. The typical Irish dairy farm has

Received May 5, 2011.

Accepted September 30, 2011.

${ }^{1}$ Corresponding author: Doris.Laepple@teagasc.ie a grazing season from early spring to late autumn, which implies that dairy cows graze freely outdoors on green pastures for most of the year. Compared with other European countries, Ireland has a climate that is well suited to grass growth between April and October (Hennessy and Roosen, 2003). One of its major competitive advantages is the potential to produce between 12 and 16 tonnes of grass DM per hectare over a long growing season (O'Donovan et al., 2010). Generally, a strong relationship has been shown between the total costs of production and the proportion of grazed grass in the dairy cow diet in several countries (Dillon et al., 1995). This relationship indicates that the average cost of milk production is decreased by over 1 cent/L for a $2.5 \%$ increase in grazed grass in the cow diet. The data also demonstrates that a considerable proportion of the dairy cow diet (over 50\%) must comprise grazed grass before a significant effect on the cost of production is realized.

Irish dairy production systems are predominantly based on a combination of grazed grass, grass silage, and concentrate (Dillon et al., 1995), but it is now widely accepted that grazed grass is the cheapest feed available on most Irish dairy farms (O'Donovan et al., 2010). Thus, there has been a recent movement toward increasing grazed grass by simultaneously decreasing the proportion of grass silage and concentrate offered to the lactating animal. However, despite this effort, the efficiency of grass utilization on average Irish dairy farms, at approximately $60 \%$, is still relatively low and requires significant improvement to secure the competitiveness of the sector. In recent years, grazing management strategies have been identified to increase the proportion of grazed grass and to decrease the dependency on indoor feeding in Irish dairy systems. In addition, continued technical innovation in grazing management is regarded to have the potential to further decrease the cost of milk production and, therefore, underpin the viability of these industries. The efficiency of grass utilization on average Irish dairy farms can be improved through several means; for example, through increased stocking rate, adopting new grass varieties, applying modern grazing management technologies, or lengthening of the grazing season. The focus of this study is on 
the potential and economic consequences of lengthening the grazing season.

The overall goal of this study was to estimate the cost implications of an extended grazing season as a means to improve the competitiveness of the dairy sector, which was achieved through 2 main objectives. The first objective was to determine the farm location, farm, and farmer characteristics associated with the length of the grazing season. Here, the aim was to provide information whether factors other than farm location characteristics are linked to the length of the grazing season and, thereby, to establish whether an extension of the grazing season is feasible. The second objective was to quantify the cost implications associated with a longer grazing season.

\section{MATERIALS AND METHODS}

\section{Data}

The main data source used in this analysis is the Irish National Farm Survey (NFS; Connolly et al., 2010). The NFS was established in 1972 and has been published on an annual basis since then. The NFS is collected as part of the Farm Accountancy Data Network of the European Union, providing a representative sample of Irish farms. Overall, approximately 1,100 farms are included in the survey each year, representing a farming population of 110,000 farms. Many farmers stay in the sample for several years and the sample has a yearly turnover rate of approximately 15 to $20 \%$. After a certain period, farms drop out and new farms are introduced to keep the sample representative and at the approximate 1,100 figure. Farms are classified into farming systems, based on dominant farm enterprise, which is calculated on a standard gross margin basis. The NFS distinguishes between 6 farming systems: specialized dairying, dairying other, cattle rearing, cattle other, mainly sheep, and tillage. In this paper, a subsample of NFS farms comprising specialized dairy farms is used.

The set of variables collected by the survey is updated on a regular basis, meaning that new information becomes available in some years. For example, this analysis uses data on the grazing season length, which first became available in 2008. In addition, data from an NFS supplementary survey for 2009 were available, providing more detailed information on grassland management. The supplementary survey includes, among other information, data on the farm area that has been re-seeded within the last $3 \mathrm{yr}$, details on grassland management practices, and factors that limit the possibility of moving dairy cows to grass.
The analysis of the length of the grazing season is based on a cross-section sample from 2009, as information from the 2009 supplementary survey is included. In contrast, the economic analysis is based on a 2-yr panel data set from 2008 and 2009. The panel is unbalanced in the sense that not all farmers are in the sample for both years. In 2008, 324 specialist dairy farms were in the sample, whereas this figure decreased to 276 in 2009. Seventy percent of farms are in the sample for both years, and the remaining $30 \%$ are either only in $2008(22 \%)$ or only in $2009(8 \%)$.

Before embarking on an analysis of the length of the grazing season, it is important to provide explanations for relevant terms used. The length of the grazing season is defined as follows: farmers participating in the NFS (from 2008 onwards) were asked when they first moved their dairy cows to grass by day, full-time, and when they were housed. The length of the grazing season is calculated in days and estimated as the difference between the date when dairy cows are moved to grass and the date when cows are housed, with out by day constituting half of a grazing day. The length of the grazing season is then adjusted for calving pattern, assuming that dairy cows are housed until calving.

The measure of production costs used in this study is direct costs per liter. Direct costs include all costs directly incurred in dairy production (e.g., feeding stuffs and fertilizer, but excluding the farmer's own unpaid labor). Because economic data are highly dependent on farm size, these figures are reported on a per-liter basis. It is important to accurately adjust variables for comparative purposes, also stressed by Dartt et al. (1999) and Gloy et al. (2002).

\section{Statistical Methods}

The effect of location and various farm and farmer characteristics on the length of the grazing season was estimated with ordinary least square (OLS) regression analysis. This analysis is based on a cross-section sample from 2009, due to the fact that some of the explanatory variables were retrieved from the supplementary survey, which was only available for 2009. The explanatory variables included in the OLS model consist of dummy variables as well as continuous variables.

In a separate statistical analysis, the effect of grazing on production costs (i.e., direct costs per liter were estimated with a random effects panel data model encompassing NFS data from 2008 and 2009). Due to little within variation in the main explanatory variable, the length of the grazing season, a random effects model was chosen, as a fixed effects model may not provide good estimates (Cameron and Trivedi, 2010). 
Table 1. Descriptive statistics (means and SD in parentheses) for the sample (2009)

\begin{tabular}{|c|c|c|c|c|c|c|}
\hline \multirow[b]{2}{*}{ Item } & \multirow[b]{2}{*}{ National } & \multicolumn{4}{|c|}{ Region in Ireland ${ }^{1}$} & \multirow[b]{2}{*}{ Difference $^{2}$} \\
\hline & & BMW & Southwest & East & South & \\
\hline Sample farms (n) & 276 & 52 & 55 & 75 & 94 & \\
\hline Weighted population & 16,527 & 3,864 & 5,337 & 2,513 & 4,813 & \\
\hline \multicolumn{7}{|l|}{ Variable } \\
\hline Grazing season $(\mathrm{d})$ & $\begin{array}{l}223.22 \\
(22.60)\end{array}$ & $\begin{array}{l}205.04 \\
(21.78)\end{array}$ & $\begin{array}{l}222.78 \\
(24.14)\end{array}$ & $\begin{array}{l}233.05 \\
(21.06)\end{array}$ & $\begin{array}{l}233.27 \\
(22.35)\end{array}$ & $F=16.59^{* *}$ \\
\hline Soil class $1^{3}(1=$ yes $)$ & $\begin{array}{c}0.53 \\
(0.49)\end{array}$ & $\begin{array}{c}0.26 \\
(0.45)\end{array}$ & $\begin{array}{c}0.47 \\
(0.50)\end{array}$ & $\begin{array}{c}0.68 \\
(0.47)\end{array}$ & $\begin{array}{c}0.61 \\
(0.49)\end{array}$ & $\chi^{2}=23.89^{* *}$ \\
\hline $\mathrm{UAA}^{4}$ (ha) & $\begin{array}{l}51.58 \\
(27.43)\end{array}$ & $\begin{array}{l}39.56 \\
(20.33)\end{array}$ & $\begin{array}{l}53.15 \\
(26.14)\end{array}$ & $\begin{array}{c}62.12 \\
(32.22)\end{array}$ & $\begin{array}{c}54.00 \\
(32.06)\end{array}$ & $F=8.38^{* *}$ \\
\hline Herd size & $\begin{array}{c}49.02 \\
(26.36)\end{array}$ & $\begin{array}{l}38.39 \\
(22.57)\end{array}$ & $\begin{array}{l}51.19 \\
(24.44)\end{array}$ & $\begin{array}{l}53.39 \\
(28.03)\end{array}$ & $\begin{array}{l}52.87 \\
(27.23)\end{array}$ & $F=3.87^{*}$ \\
\hline Stocking density $(\mathrm{LU} / \mathrm{ha})^{5}$ & $\begin{array}{c}1.11 \\
(0.42)\end{array}$ & $\begin{array}{c}1.10 \\
(0.44)\end{array}$ & $\begin{array}{c}1.13 \\
(0.41)\end{array}$ & $\begin{array}{c}1.04 \\
(0.41)\end{array}$ & $\begin{array}{l}1.15 \\
(0.43)\end{array}$ & $F=0.92$ \\
\hline Milk per cow (L/cow) & $\begin{array}{r}4,471.75 \\
(973.07)\end{array}$ & $\begin{array}{r}4,513.66 \\
(964.63)\end{array}$ & $\begin{array}{c}4,068.35 \\
(993.15)\end{array}$ & $\begin{array}{c}4,639.14 \\
(1,065.20)\end{array}$ & $\begin{array}{c}4,798.02 \\
(909.48)\end{array}$ & $F=4.87^{* *}$ \\
\hline Concentrates (kg/cow) & $\begin{array}{c}854.91 \\
(417.94)\end{array}$ & $\begin{array}{c}1,119.01 \\
(502.47)\end{array}$ & $\begin{array}{c}744.89 \\
(452.86)\end{array}$ & $\begin{array}{c}734.80 \\
(408.69)\end{array}$ & $\begin{array}{c}827.61 \\
(316.18)\end{array}$ & $F=6.76^{* *}$ \\
\hline Age of farmer (yr) & $\begin{array}{c}50.79 \\
(10.22)\end{array}$ & $\begin{array}{l}50.81 \\
(9.44)\end{array}$ & $\begin{array}{l}50.18 \\
(9.33)\end{array}$ & $\begin{array}{c}52.39 \\
(10.94)\end{array}$ & $\begin{array}{c}50.62 \\
(11.49)\end{array}$ & $F=0.59$ \\
\hline Higher education $^{6}$ & $\begin{array}{c}0.72 \\
(0.44)\end{array}$ & $\begin{array}{c}0.73 \\
(0.44)\end{array}$ & $\begin{array}{c}0.79 \\
(0.40)\end{array}$ & $\begin{array}{c}0.72 \\
(0.45)\end{array}$ & $\begin{array}{c}0.63 \\
(0.48)\end{array}$ & $\chi^{2}=1.45$ \\
\hline Member of discussion group ( $1=$ yes $)$ & $\begin{array}{c}0.25 \\
(0.42)\end{array}$ & $\begin{array}{c}0.18 \\
(0.39)\end{array}$ & $\begin{array}{c}0.18 \\
(0.38)\end{array}$ & $\begin{array}{c}0.29 \\
(0.45)\end{array}$ & $\begin{array}{c}0.35 \\
(0.48)\end{array}$ & $\chi^{2}=8.71^{*}$ \\
\hline More than $10 \%$ of the farm reseeded $(1=$ yes $)$ & $\begin{array}{c}0.42 \\
(0.47)\end{array}$ & $\begin{array}{c}0.26 \\
(0.44)\end{array}$ & $\begin{array}{c}0.37 \\
(0.48)\end{array}$ & $\begin{array}{c}0.37 \\
(0.48)\end{array}$ & $\begin{array}{c}0.64 \\
(0.48)\end{array}$ & $\chi^{2}=28.71^{* *}$ \\
\hline
\end{tabular}

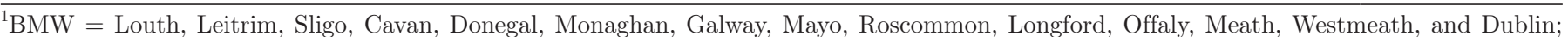
southwest $=$ Kerry, Clare, Limerick, and Tipperary; east $=$ Kildare, Wicklow, Laois, Carlow, Kilkenny, and Wexford; south $=$ Waterford and Cork.

${ }^{2}$ Indicates whether or not a significant difference exists in the means of variables broken down by regions based on an $F$-test or $\chi^{2}$ test. A $\chi^{2}$ test was used on the following variables: soil class, higher education, member of discussion group, and $10 \%$ of farm reseeded; an $F$-test was used on all other variables. All statistical tests were conducted in the program Stata 11 (StataCorp LP, College Station, TX).

${ }^{3}$ Very good soils are soils that are classified as having no or minor limitations for use.

${ }^{4}$ Utilizable agricultural area (UAA) is defined as the area under crops and pasture plus the area of rough grazing.

${ }^{5} \mathrm{LU}=$ livestock units.

${ }^{6}$ Higher education implies that the farmer has completed secondary education or received a university degree (i.e., bachelor's or master's degree). ${ }^{* *} P<0.01 ; * P<0.05$.

All statistical analyses were conducted in the statistical package Stata 11 (StataCorp, 2009).

\section{RESULTS AND DISCUSSION}

\section{Descriptive Analysis}

Descriptive statistics for the sample from 2009 are reported in Table 1, divided into 4 regions: the border, midlands, and western (BMW); southwest; east; and south regions $(\mathrm{BMW}$ region $=$ Louth, Leitrim, Sligo, Cavan, Donegal, Monaghan, Galway, Mayo, Roscommon, Longford, Offaly, Meath, Westmeath, and Dublin; southwest region $=$ Kerry, Clare, Limerick, and Tipperary; east region $=$ Kildare, Wicklow, Laois, Carlow, Kilkenny, and Wexford; south region= Waterford and Cork). Each of the 4 regions has unique characteristics regarding dairy production. Whereas the south and the southwest are mainly dairy production regions on free-draining soils, the BMW region is characterized by lower stocking density based on gley soils and higher rainfall areas. Differences between the regions are assessed using statistical tests. More specifically, a 1-way ANOVA is used for continuous variables, with region as a class variable and a contingency analysis by region was conducted for categorical variables.

To begin with the length of the grazing season, the figures in Table 1 reveal some notable variation between the regions $(F=16.59 ; P<0.01)$. Farms in the BMW region have a shorter grazing season, with an average of $205 \mathrm{~d}$, than all other regions.

Although the grazing season length on Irish farms is characterized by large variation across farms, it varied little over the 2 observed years. For example, the average date at which dairy cows were moved to grass by day in 2008 and 2009 was at the beginning of March (2008: March 4; 2009: March 3), with a variation from the middle of January to the beginning of May. 
Similarly, the dates when cows were housed at the end of the year largely match over the 2 yr. On average, cows were housed at the beginning of November (2008: November 3; 2009: November 4), with a variation from the end of September to the end of December.

The variation in grazing season lengths across farms may be mainly driven by differences in soil quality and climate between the regions. In this study, soil class is divided into three categories: very good, good, and moderate. Very good soils are soils that are classified as having no or minor limitations for use. Good soils are soils that are classified as having limited use range, which are soils that are unsuited to tillage but suited to permanent grassland systems. Moderate soils are classified as soils with very limited use range, which restrict agricultural production (Connolly et al., 2010). In Table 1, it can be seen that the BMW region has a lower proportion of farms on very good soils (26\%) than, for example, the southern region, where over $60 \%$ of the farms are on very good soils. More detailed data analysis shows that in the BMW region in areas with moderate soils, $10 \%$ of farmers had a grazing season of over $220 \mathrm{~d}$ compared with an average grazing season of $205 \mathrm{~d}$ in that region. In Ireland, the national research target for grazing season length is $300 \mathrm{~d}$ (O'Donovan et al., 2010), but research has proven that it is possible to consistently achieve a 270-d grazing season length in less-advantaged areas( i.e., the BMW region; Patton et al., 2011). This indicates potential for dairy farmers to lengthen their grazing season. To further support this statement, estimates of annual DM grass production and grass-growing days in Ireland indicate that annual DM decreases from the southwest to the northeast and in line with that, estimated dates when dairy cows are moved to grass are later in the year in the northeast (Brereton, 1995). However, the data of the present analysis shows that farmers in the southwestern region have a shorter grazing season length than farmers in the east. This strongly suggests that factors other than farm location characteristics have an effect on the length of the grazing season, a theory that is tested in the following econometric analysis.

In terms of farm size (see Table 1), notable differences exist between the regions $(F=8.38 ; P<0.01)$. Farms in the east are larger than farms in all other regions, measured in utilizable agricultural area. Dairy farmers in the BMW region offered the highest amount of concentrates, with an average of over 1,100 kg per cow.

Nationally, fewer than one-third of dairy farmers participate in discussion groups (see Table 1). Discussion groups are farm extension meetings of a group of farmers organized by a dairy advisor/farm consultant. The groups meet approximately every 2 mo to discuss a specific topic (i.e., grazing management, AI bull selection, production costs, or mastitis prevention). In 2009, $35 \%$ of farmers in the south participated in discussion groups, whereas less than $20 \%$ of farmers participated in the BMW and southwestern regions. In terms of grassland management, $26 \%$ of farmers in the BMW region reseeded at least $10 \%$ of their farming area within the last $3 \mathrm{yr}$, which is less than the proportion reseeded in all other regions. Generally, reseeding parts of the land area is regarded as increasing grass supply.

Measurements of economic performance of dairy farms are shown in Table 2. The farms within the regions differ regarding concentrate costs $(F=8.72$; $P<0.01)$ and gross margins $(F=3.15 ; P<0.05)$. With $\$ 0.07$ per liter, farms in the BMW region have the highest costs for concentrates. When overhead costs are factored in, farms in the BMW region have negative net margins of $\$-0.01$ per liter, whereas farms in the southern region achieve net margins of $\$ 0.03$ per liter. Net margins achieved in the BMW region are typically lower than in the other regions. Overhead costs for dairying are not directly available from NFS data, but are calculated based on the proportion of farm gross output originating from the dairy enterprise. Overhead costs are fixed costs including, for example car, electricity, interest charges, machinery, and building depreciation (Connolly et al., 2010).

When considering net margins, it is important to take account that in 2009 milk prices in Ireland were at an extremely low level, averaging $\$ 0.28$ per liter, whereas the average price in the preceding 3 yr was $\$ 0.40$ per liter (Donnellan and Hennessy, 2011). The fact that average net margins in 2008 were $\$ 0.11$ per liter, further underscores the effect of low milk prices on net margins.

Farmers' views on limiting factors of the length of the grazing season, which were elicited in the supplementary survey, were as follows: climatic conditions were identified as the main reason influencing the date at which dairy cows were moved to grass, as stated by $64 \%$ of farmers, followed by grass supply as the next most important factor, mentioned by over $20 \%$ of farmers. Other factors restricting the date dairy cows were moved to grass were soil quality $(6 \%)$, personal reasons such as preferring to house cows until early March, or lack of necessary infrastructure. These reasons were also reflected in a previous survey carried out by Creighton et al. (2011).

With intensive grazing systems, good management practices are required to optimize the overall feed rationing of grazing dairy cows. In this context large differences exist in how grass is allocated to the grazing dairy cows. Data of the supplementary survey showed that $40 \%$ of all Irish dairy farmers strip grazed their 
Table 2. Descriptive statistics (means and SD in parentheses) for economic characteristics (2009)

\begin{tabular}{|c|c|c|c|c|c|c|}
\hline \multirow[b]{2}{*}{ Variable } & \multirow[b]{2}{*}{ National } & \multicolumn{4}{|c|}{ Region in Ireland $^{1}$} & \multirow[b]{2}{*}{ Difference $^{2}$} \\
\hline & & BMW & Southwest & East & South & \\
\hline Gross output $(\$ / L)$ & $\begin{array}{c}0.31 \\
(0.04)\end{array}$ & $\begin{array}{c}0.31 \\
(0.03)\end{array}$ & $\begin{array}{c}0.31 \\
(0.04)\end{array}$ & $\begin{array}{c}0.32 \\
(0.04)\end{array}$ & $\begin{array}{c}0.31 \\
(0.08)\end{array}$ & $F=0.68$ \\
\hline Direct cost $(\$ / \mathrm{L})$ & $\begin{array}{c}0.17 \\
(0.05)\end{array}$ & $\begin{array}{c}0.19 \\
(0.04)\end{array}$ & $\begin{array}{c}0.17 \\
(0.04)\end{array}$ & $\begin{array}{c}0.16 \\
(0.12)\end{array}$ & $\begin{array}{c}0.16 \\
(0.04)\end{array}$ & $F=1.78$ \\
\hline Concentrates $(\$ / \mathrm{L})$ & $\begin{array}{c}0.05 \\
(0.03)\end{array}$ & $\begin{array}{c}0.07 \\
(0.03)\end{array}$ & $\begin{array}{c}0.05 \\
(0.03)\end{array}$ & $\begin{array}{c}0.05 \\
(0.03)\end{array}$ & $\begin{array}{c}0.05 \\
(0.01)\end{array}$ & $F=8.72^{* *}$ \\
\hline Gross margin $(\$ / L)$ & $\begin{array}{c}0.13 \\
(0.07)\end{array}$ & $\begin{array}{c}0.12 \\
(0.07)\end{array}$ & $\begin{array}{c}0.13 \\
(0.07)\end{array}$ & $\begin{array}{c}0.15 \\
(0.09)\end{array}$ & $\begin{array}{c}0.15 \\
(0.04)\end{array}$ & $F=3.15^{*}$ \\
\hline Net margin $(\$ / L)$ & $\begin{array}{c}0.01 \\
(0.08)\end{array}$ & $\begin{array}{c}-0.01 \\
(0.08)\end{array}$ & $\begin{array}{c}0.01 \\
(0.07)\end{array}$ & $\begin{array}{c}0.00 \\
(0.16)\end{array}$ & $\begin{array}{c}0.03 \\
(0.07)\end{array}$ & $F=1.59$ \\
\hline
\end{tabular}

${ }^{1}$ BMW = Louth, Leitrim, Sligo, Cavan, Donegal, Monaghan, Galway, Mayo, Roscommon, Longford, Offaly, Meath, Westmeath, and Dublin; southwest $=$ Kerry, Clare, Limerick, and Tipperary; east $=$ Kildare, Wicklow, Laois, Carlow, Kilkenny, and Wexford; south $=$ Waterford and Cork.

${ }^{2}$ Indicates whether or not a significant difference exists in the means of variables broken down by regions based on an $F$-test. All statistical tests were conducted in the program Stata 11 (StataCorp, 2009).

${ }^{* *} P<0.01 ;{ }^{*} P<0.05$.

cows every $12 \mathrm{~h}$, whereas almost $20 \%$ of farmers allocated grass to the dairy herd every 24 to $48 \mathrm{~h}$. Thirty-two percent of Irish dairy farmers used the entire paddock at once, whereas $8 \%$ used the entire field at once. A paddock is defined as a subsection of a field (i.e., allowing dairy cows to access parts of the field). In addition, supplementary survey data indicated that grassland management varies considerably between the regions. For example, over $60 \%$ of farmers strip graze their cows in the south, whereas this figure is less than $20 \%$ in the BMW region. In contrast, almost $50 \%$ of farmers in the BMW region graze their cows on the entire paddock, whereas only $15 \%$ of farmers in the south use this grassland management technique. In the past decade, there has been increased awareness that the layout of the farm needs to facilitate a more planned approach to grass utilization. Grazing paddocks are now planned and access roadways, water troughs, and individual paddocks are set out on dairy farms (French and Van Bysterveldt, 2011). It is clear from this analysis that in the dairy populated regions (southern Ireland), this message is more widely practiced than in the nondairy specialized regions (BMW region).

Overall, the data reveals large variation in the methods that farmers use to manage grazing on their farms. Generally, farms that have grazing paddocks with roadway networks are more likely to use grass earlier and later in the grazing season than farms with old-fashioned field layouts. It is obvious that different strategies in action exist on farms. The question emerging from this is whether or not the different grazing management approaches have an effect on the length of the grazing season, which will be explored empirically in the following section.

\section{Factors Affecting Grazing Season Length}

The effect of farm location factors, farm, and farmer characteristics on the length of the grazing season was estimated by means of OLS regression analysis. The explanatory variables included regional and soil quality dummy variables, structural variables, such as herd size and livestock units per ha (LU/ha), farmer characteristics, such as age of farmer and education, as well as a dummy variable indicating whether or not the cows have been housed before the first week of November in the previous year (i.e., 2008). The estimation results are presented in Table 3.

The model indicates a good fit based on a statistically significant $F$-value $(22.26 ; 17 \mathrm{df})$ and an adjusted coefficient of determination of 0.62 , a very good level for a cross-sectional model estimated on a small sample. Because region and soil quality may be correlated, multicollinearity was tested via variance inflation factors. Generally, variance inflation factors greater than 10 suggest collinearity (Greene, 2008). In this analysis, all variance inflation factors were smaller than 10; therefore, it was assumed that multicollinearity was not an issue.

Following a priori expectations, the results of the model confirmed a statistically significant effect of region and soil type on the length of the grazing season. For example, the time cows spent outside grazing was 12 $\mathrm{d}$ longer in the southwest and $16 \mathrm{~d}$ longer in the eastern and southern regions in comparison to the BMW region when all other factors were controlled. Furthermore, cows on good and moderate soils were grazed for $7 \mathrm{~d}$ less, in comparison with cows grazed on very good soils. The variable denoting whether or not cows were housed 
Table 3. Factors affecting grazing season length

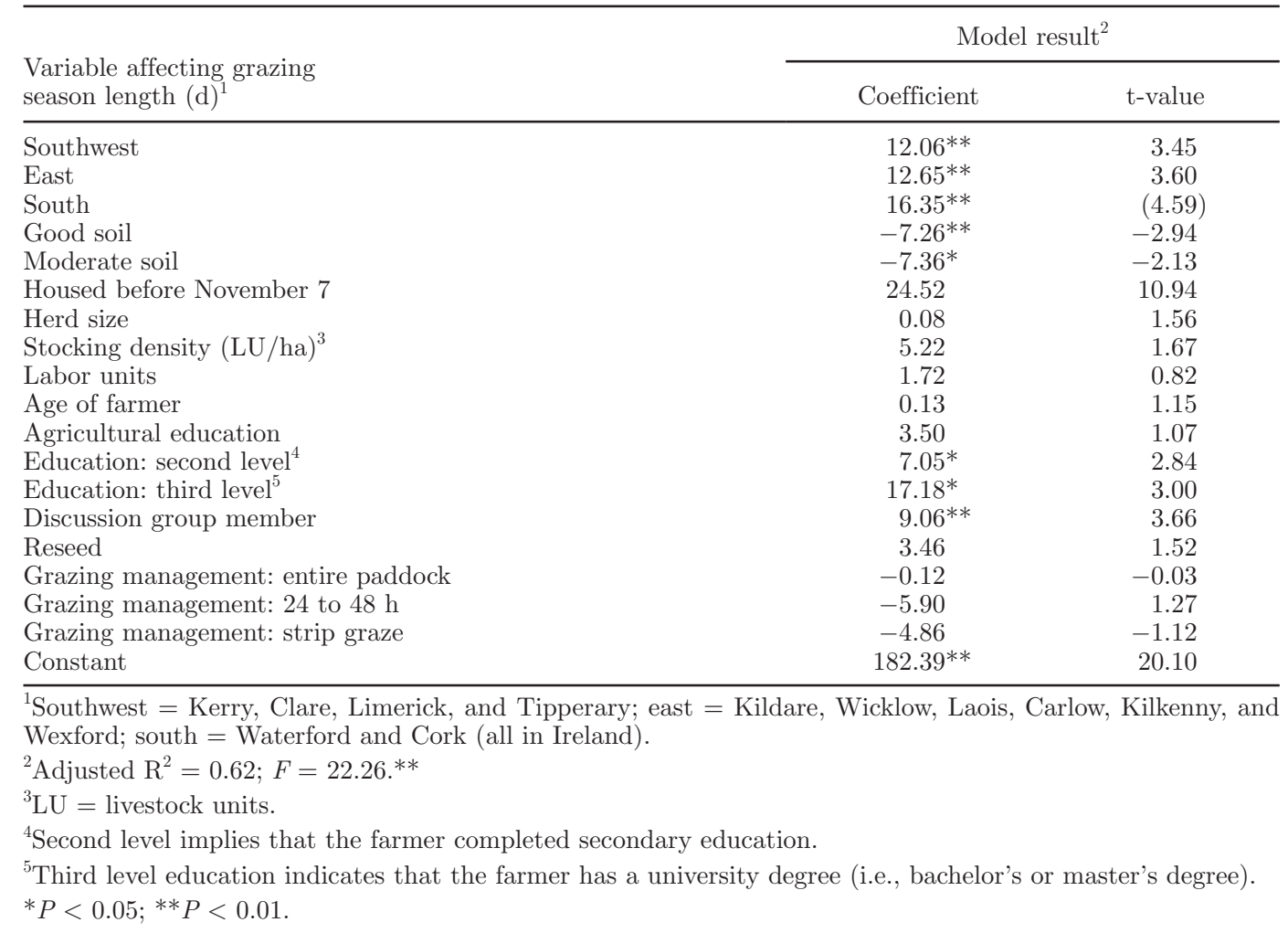

before November 7, 2008, was positively significantly correlated to the length of the grazing season. This indicates that farmers that housed their cows later in the previous season still tended to have longer grazing seasons in the subsequent year. This is despite the fact that delaying the closing of paddocks toward the end of the grazing season reduced spring grass mass significantly (O'Donovan and Kennedy, 2007).

In terms of farm characteristics, farm size measured in size of dairy herd, stocking density (LU/ha), and total labor units on the farm had no statistical significant effect on the grazing season. Similarly, Hanson et al. (1998) found no statistical significant effect of stocking rate on the intensity of grazing management.

When farmer characteristics were investigated, the age of the farmer was not found to be related to grazing season, which is in contrast to findings of Hanson et al. (1998), who found younger farmers to be more likely to use moderate intensive grazing systems. The results of the present analysis also suggested that farmers with higher education (second- or third-level education) tend to graze their cows longer in comparison with farmers that have a pre-school or primary level education. Similarly, Parsons et al. (2004) found that farmers who used intensive grazing were higher educated than farmers that managed confinement systems. Further, intensive grazing of dairy cows can be difficult to carry out, because it requires good management to evaluate grass cover and to determine when to move cows from one paddock to the next. Discussion group membership was associated with a longer grazing season. This means that members of discussion groups are applying knowledge and technology received through their groups to extend the grazing season on their farms. Whether or not more than $10 \%$ of the farm area was reseeded within the last $3 \mathrm{yr}$ was not found to affect the length of the grazing season, although reseeding is likely to increase grass supply.

Accounting for different grassland management practices was also not found to have a significant effect on grazing season length. This relationship was tested by the inclusion of dummy variables. The results suggest no statistically significant difference between grazing season length as to whether or not farmers strip grazed their cows every $12 \mathrm{~h}$, moved them every 24 to $48 \mathrm{~h}$, or used the entire field or paddock at once. This implies that better/different grassland management does not necessarily imply a longer grazing season, as the main goal is to efficiently convert grass to milk.

\section{Economic Analysis of Grazing Season Length}

The effects of grazing season length, regional dummy variables interacting with grazing season length, as 
Table 4. Factors affecting direct costs per liter

\begin{tabular}{lcr}
\hline & \multicolumn{2}{c}{ Model result $^{2}$} \\
\cline { 2 - 3 } Variable affecting & Coefficient & z-value \\
\hline direct costs (cent/L) & $-0.16^{* *}$ & -2.31 \\
Grazing days & $0.0003^{\dagger}$ & 1.83 \\
Grazing days squared & $-0.006^{*}$ & -2.06 \\
Southwest $^{3}$ & $-0.01^{* *}$ & -3.55 \\
East $^{3}$ & $-0.006^{*}$ & -2.36 \\
South $^{3}$ & $1.12^{*}$ & 2.47 \\
Small herd $\left(<40\right.$ cows) $_{\text {Large herd (>90 cows) }}$ & $0.99^{\dagger}$ & 1.82 \\
Year & $-1.17^{* *}$ & -5.75 \\
Constant & $40.91^{* *}$ & 5.07 \\
\hline
\end{tabular}

${ }^{1}$ Southwest $=$ Kerry, Clare, Limerick, and Tipperary; east $=$ Kildare, Wicklow, Laois, Carlow, Kilkenny, and Wexford; south = Waterford and Cork (all in Ireland).

${ }^{2} \mathrm{R}^{2}=0.24 ;$ rho $=0.69$.

${ }^{3}$ Interaction variable with grazing days.

${ }^{4}$ Year: $1=2009$.

$\dagger P<0.1 ;{ }^{*} P<0.05 ;{ }^{*} P<0.01$.

well as dummy variables accounting for herd size on direct costs per liter were assessed with a random effects model. The results of the model are presented in Table 4.

The model results indicated that extending the grazing season by $1 \mathrm{~d}$ implied a 0.16 -cent decrease in direct costs of producing each liter of milk. However, this cost reduction occurred only to a certain extent (i.e., it was nonlinear, as indicated by the significant positive effect of the squared term). More specifically, based on the model results, a longer grazing season led to a decrease in direct costs up until a grazing season length of approximately $290 \mathrm{~d}$. Thus, the model suggested that cost savings are possible even with a very long grazing season.

The analysis accounted for regional differences of grazing season length on direct costs by the inclusion of interaction terms of regional dummy variables and grazing season length. Due to multicollinearity and limited sample size, only interaction variables but no indicator variables (i.e., regional dummy variables) were included in the analysis. The findings indicated that the highest cost savings (in comparison to the BMW region) due to an extended grazing season could be achieved in the eastern region. This suggests that other economic factors, such as veterinarian or contractor costs decrease due to a longer grazing season.

The effect of herd size was measured by means of a dummy variable, specified as small herds, mediumsized herds, and large herds. Although herds with less than 40 cows were associated with higher direct costs in comparison with medium-sized herds, large herds (over 90 cows) also had a positive effect on direct costs per liter, suggesting decreasing marginal returns to scale (i.e., initially, costs decrease as scale increases but then they begin to rise again beyond a certain herd size).

The negative effect of the time dummy for 2009 indicated that higher costs savings were possible in 2009 in comparison with 2008. This result is confirmed by the fact that production costs on Irish dairy farms decreased by $8 \%$ in the period between 2008 and 2009 (Donnellan and Hennessy, 2011).

\section{Economic Effects}

The results from the previous analysis indicated that lengthening the grazing season by $1 \mathrm{~d}$ resulted in a cost reduction of 0.16 cent per liter in 2009. This would imply that lengthening the grazing season from 233 to 243 d (i.e., $10 \mathrm{~d}$ ) on a medium-sized farm in the eastern region would decrease the direct costs of production from 14.6 cents per liter to 14.2 cents per liter. In Figure 1, the development of direct costs on a medium-sized and a small farm in the eastern region are shown for 2009. As is evident, direct costs were higher on smaller farms and decreased significantly on both farms with a longer grazing season.

By aggregating this effect up to farm level, lengthening the grazing season for $10 \mathrm{~d}$ on a typical farm in the eastern region with a herd of 53 cows and a milk yield of 4,640 L would save the average farmer approximately $\$ 1,000$ annually. In contrast, for a typical farm in the BMW region with 38 cows and yielding 4,513 L of milk, extending the grazing season from 205 to $215 \mathrm{~d}$ would lead to cost savings of $\$ 790$.

It is evident that potential exists for dairy farmers to decrease costs by extending the grazing season. Although the above figures are based on an average Irish dairy farm, cost savings and the potential to extend

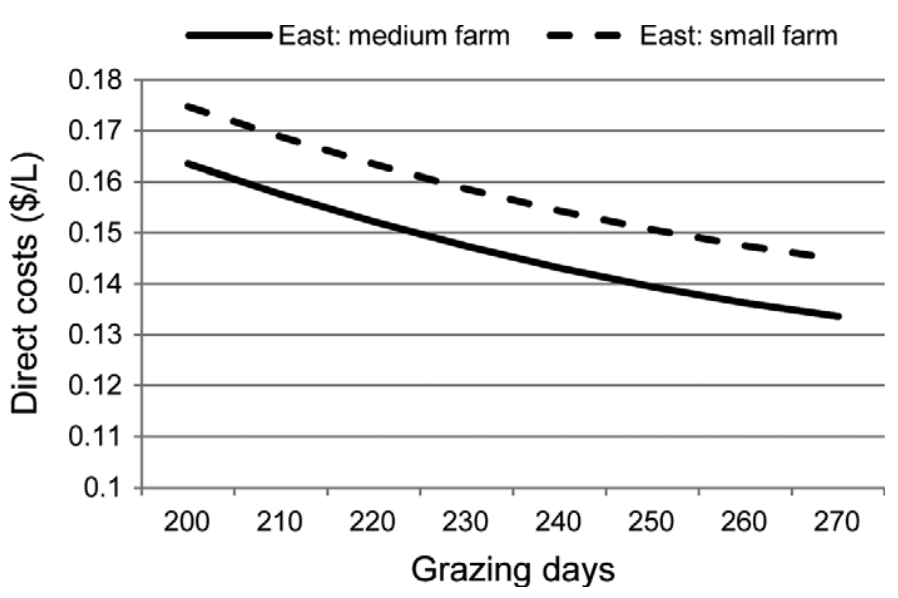

Figure 1. Development of direct costs with grazing season length. 
the grazing season are expected to vary considerably between farms.

\section{CONCLUSIONS}

Internationally, Ireland has a competitive advantage due to its favorable climate and its capacity to consistently grow between 12 and 16 tonnes of grass DM per hectare. This allows grass-based milk production to take place at low costs. To stay competitive in the global food market, it is paramount that Ireland fully exploits its "green" advantage and maximizes the level of grass utilization on dairy farms. Currently, grass utilization on Irish dairy farms is suboptimal and requires significant improvement to further decrease production costs. In this study, the focus was on lengthening the grazing season as a means of improving grass utilization and, thereby, improving farm cost structure. More specifically, the effects of farm location, farm, and farmer characteristics on the grazing season length, as well as the economic consequences that arise from lengthening the grazing season were explored. The grazing season length on Irish dairy farms is characterized by a large variation in duration both between regions and across farms. According to farmers' own views, the main factors limiting the length of the grazing season were climatic conditions and soil quality. Nevertheless, the empirical results in this study indicated that not only climatic conditions and soil quality affect the length of the grazing season, but farmer characteristics, such as education level and discussion group membership are also linked to achieving a longer grazing season. The findings of the economic analysis showed that lengthening the grazing season leads to a decrease in overall direct costs. These costs savings were subject to regional variability, ranging from approximately $\$ 790$ per annum for a farm in the BMW region to $\$ 1,000$ per annum for a farm located in the eastern region. Overall, the results of this study indicated that even in disadvantaged areas with poor soils, where grazing seasons tends to be shorter, the ability exists to extend the grazing season by the application of knowledge and technologies gained through extension and education.

\section{REFERENCES}

Brereton, A. J. 1995. Regional and year to year variation in production. Pages 12-22 in Irish Grasslands-Their Biology and Manage- ment. D. W. Jeffrey, M. B. Jones, and J. H. McAdam, ed. Dublin Royal Irish Academy, Dublin, Ireland.

Cameron, A. C., and P. K. Trivedi. 2010. Microeconometrics Using Stata. Rev. ed. Stata Press, College Station, TX.

Connolly, L., A. Kinsella, and B. Moran. 2010. The National Farm Survey 2009. Teagasc, Athenry, Ireland.

Creighton, P., E. Kennedy, T. Boland, L. Shalloo, and M. O'Donovan. 2011. A survey analysis of grassland dairy farming in Ireland, investigating grassland management, technology adoption and sward renewal. Grass Forage Sci. 66:251-264.

Dartt, B. A., J. W. Lloyd, B. R. Radke, J. R. Black, and J. B. Kaneene. 1999. A comparison of profitability and economic efficiencies between management-intensive grazing and conventionally managed dairies in Michigan. J. Dairy Sci. 82:2412-2420.

Dillon, P., S. Crosse, G. Stakelum, and F. Flynn. 1995. The effect of calving date and stocking rate on the performance of springcalving dairy cows. Grass Forage Sci. 50:286-299.

Dillon, P. G., T. Hennessy, L. Shalloo, and F. Thorne. 2008. Future outlook for the Irish dairy industry: A study of international competitiveness, influence of international trade reform and requirement for change. Int. J. Dairy Technol. 61:16-29.

Donnellan, T., and T. Hennessy. 2011. The situation and outlook for the dairy sector. Pages 17-45 in Proc. Teagasc Situation and Outlook Conf., Portlaoise, Ireland. Teagasc, Athenry, Ireland.

French, P., and A. Van Bysterveldt. 2011. Infrastructural requirements for a Greenfield dairy farm. Pages $9-47$ in Proc. Teagasc Greenfield Dairy Program; Moorepark Dairy Levy Research Update. Moorepark Dairy Production Research Centre, Teagasc, Ireland.

Gloy, B. A., L. W. Tauer, and W. Knoblauch. 2002. Profitability of grazing versus mechanical forage harvesting on New York dairy farms. J. Dairy Sci. 85:2215-2222.

Greene, W. 2008. Econometric Analysis. 6th ed. Prentice Hall, Englewood Cliffs, NJ.

Hanson, G. D., L. C. Cunningham, M. J. Morehart, and R. L. Parsons. 1998. Profitability of moderate intensive grazing of dairy cows in the northeast. J. Dairy Sci. 81:821-829.

Hennessy, D. A., and J. Roosen. 2003. A cost-based model of seasonal production with application to milk policy. J. Agric. Econ. 54:285-312.

O'Donovan, M., and E. Kennedy. 2007. Using grass to reduce feed costs. Pages 63-80 in Proc. Teagasc National Dairy Conf., Kilkenny, Ireland. Teagasc, Carlow, Ireland.

O'Donovan, M., E. Lewis, T. Boland, and P. O'Kiely. 2010. Requirements of future grass based ruminant production systems in Ireland. Pages 11-41 in Proc. Grasses for the Future Conf., Cork, Ireland. Teagasc, Carlow, Ireland.

Parsons, R. L., A. E. Luloff, and G. D. Hanson. 2004. Can we identify key characteristics associated with grazing-management dairy systems from survey data? J. Dairy Sci. 87:2748-2760.

Patton, D., L. Shalloo, K. Pierce, and B. Horan. 2011. A comparison of alternative intensive Irish pasture based systems of spring milk production on a wetland drumlin soil in the Border midlands west region of Ireland. Page 140 in Proc. Agric. Research Forum, Teagasc, Tullamore, Ireland. Teagasc, Carlow, Ireland.

StataCorp. 2009. Stata Statistical Software. Release 11. StataCorp LP, College Station, TX.

Thorne, F., and W. A. Fingleton. 2006. Examining the relative competitiveness of milk production: An Irish case study (1996-2004). J. Int. Farm Manag. 3:1-13. 